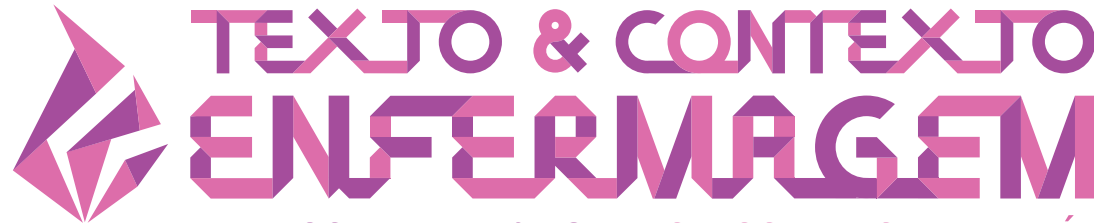

TEXT \& CONTEXT NURSING TEXTO \& CONTEXTO ENFERMERÍA

\section{REASONS FOR WOMEN'S AUTONOMOUS ACTIONS IN THE CHILDBIRTH PROCESS: AN UNDERSTANDING BASED ON SOCIAL PHENOMENOLOGY}

\author{
Fernanda Honnef ${ }^{1}$ (D) \\ Stela Maris de Mello Padoin ${ }^{1}$ (i) \\ Cristiane Cardoso de Paula ${ }^{1}$
} 1Universidade Federal de Santa Maria, Programa de Pós-Graduação em Enfermagem. Santa Maria, Rio Grande do Sul, Brasil.

\begin{abstract}
Objective: to describe women's autonomous actions during childbirth and to understand their reasons. Method: qualitative research designed through social phenomenology premises. Phenomenological interviews were conducted with 15 postpartum women hospitalized at a hospital's rooming-in setting in the south of Brazil, from September to December 2017. For the analysis, the principles of the adopted framework were followed, associated with productions related to the object of study.

Results: autonomous actions were developed from the time of pregnancy and during childbirth, and their reasons derived from their previous experiences. Such experiences were signified by the fear of what they had heard or because in previous births they had experienced pain, complications and unwanted interventions; due to the bond with companions and their experience with labor and delivery.

Conclusion: the reasons for women's autonomous actions in the childbirth process are sustained on their biographical situation, set of knowledge and social relations.
\end{abstract}

DESCRIPTORS: Parturition. Maternal-infant health. Personal autonomy. Nursing. Women's health. Humanized childbirth. 


\section{RAZÕES DAS AÇÕES AUTÔNOMAS DA MULHER NO PROCESSO DE PARTO: COMPREENSÃO FUNDAMENTADA NA FENOMENOLOGIA SOCIAL}

\section{RESUMO}

Objetivo: descrever as ações autônomas das mulheres durante o parto e compreender suas razões. Método: pesquisa qualitativa delineada por meio dos pressupostos da fenomenologia social. Realizou-se entrevista fenomenológica com 15 puérperas internadas no alojamento conjunto de um hospital no Sul do Brasil, de setembro a dezembro de 2017. Para análise, foram seguidos os fundamentos do referencial adotado dialogados com produções relacionadas com o objeto de estudo.

Resultados: as ações autônomas foram desenvolvidas desde a gestação e durante o parto, e suas razões derivaram de suas experiências anteriores. Estas foram significadas pelo medo daquilo que ouviram falar ou porque nos partos anteriores tiveram dor, complicações e intervenções não desejadas; pelo vínculo com o acompanhante e porque esse possui experiência ou vivência com processo de parto e nascimento.

Conclusão: as razões para as ações autônomas das mulheres no processo de parto estão sustentadas em sua situação biográfica, bagagem de conhecimento e relações sociais.

DESCRITORES: Parto. Saúde materno-infantil. Autonomia pessoal. Enfermagem. Saúde da mulher. Parto humanizado.

\section{RAZONES DE LAS ACCIONES AUTÓNOMAS DE LAS MUJERES EN EL PROCESO DEL PARTO: COMPRENSIÓN BASADA EN LA FENOMENOLOGÍA SOCIAL}

\section{RESUMEN}

Objetivo: describir las acciones autónomas de las mujeres durante el parto y comprender sus razones.

Método: investigación cualitativa perfilada por los supuestos de la fenomenología social. Se realizó entrevista fenomenológica a 15 puérperas hospitalizadas en el alojamiento conjunto de un hospital del sur de Brasil, de septiembre a diciembre de 2017. Para el análisis, se siguieron los fundamentos del marco adoptado, dialogando con producciones relacionadas con el objeto de estudio.

Resultados: se desarrollaron acciones autónomas desde el embarazo y durante el parto y sus motivos a partir de la experiencia de las mujeres. Estos fueron significados por miedo a lo que escucharon o porque en partos anteriores tuvieron dolor, complicaciones e intervenciones no deseadas; por el vínculo con el compañero y porque tiene experiencia o experiencia con el proceso de parto y nacimiento.

Conclusión: las razones de las acciones autónomas de las mujeres en el proceso del parto se basan en su situación biográfica, conocimientos y relaciones sociales.

DESCRIPTORES: Parto. Salud materno-infantil. Autonomía personal. Enfermería. Salud de la mujer. Parto humanizado. 


\section{INTRODUCTION}

The conceptions attributed to labor and delivery have historical and cultural roots permeated by beliefs, traditions and values inscribed in society. Throughout history, such conceptions have been marked by changes in their paradigms with regard to the roles played by professionals and women. ${ }^{1-2}$ By changing the birth setting from the home environment to hospital institutions, in the mid-twentieth century, the conception of physiological childbirth was modified with the abuse of interventions that disregard the needs of each parturient. As a result, women were dismissed from their protagonism in childbirth, which segregated them from their social and cultural context, making them doubt their natural ability to give birth. ${ }^{3-4}$

The negative repercussions on maternal and perinatal health resulting from the excessive use of interventions in some contexts and the underutilization in others, associated with disrespectful and abusive behaviors in some institutional contexts, generated discontent among women. ${ }^{5-6}$ As a consequence, in the $70 \mathrm{~s}$, debates were strengthened to restore female protagonism in childbirth. 4,7

The movement achieved visibility and obtained responses from the World Health Organization (WHO) and the Ministry of Health of Brazil, who made recommendations in order to enable the restoration of the physiology of childbirth. ${ }^{8-9}$ Such recommendations had ideological strengthening aiming at promoting women's autonomy.

The WHO published a guide with recommendations for Intrapartum Care for a Positive Childbirth Experience, which advises evidence-based actions during childbirth. ${ }^{9}$ The Brazilian National Program for Humanization of Prenatal and Childbirth Care (PHPN - Programa Nacional de Humanização no PréNatal e Nascimento), the Comprehensive Assistance Program for Women's Health (PAISM - Programa de Assistência Integral à Saúde da Mulher) and the Brazilian National Policy of Comprehensive Care for Women's Health (Política Nacional de Atenção Integral à Saúde da Mulher), ${ }^{10-12}$ aim, among other objectives, to rescue the physiological character of childbirth.

Likewise, recently, the Stork Network (Rede Cegonha) strategy has been implemented, which consists of a care network aimed at ensuring women the right to reproductive planning and humanized care during pregnancy, childbirth and puerperium. ${ }^{13}$

Thus, the objectives of national and international guidelines advise professionals towards a childbirth regulated by physiology. In this context, despite the political advances in obstetric care, practices that should have been overcome are still identified, which leads to difficulties in the exercise of women's autonomy. Therefore, in order to overcome these usual interventionist practices, it is necessary to engage the social actors present in this context, ${ }^{14}$ who must be endorsed by information that support their actions, in order to promote women's autonomy in childbirth, which would indicate convergence with the childbirth humanization policy. ${ }^{15}$

In this regard, the sociocultural issues that permeate the childbirth process are considered, as well as what women decide according to their sociocultural context. In addition, when taking into account the engagement of social actors, there is the support of phenomenology and social relations premises.$^{16}$ Such premises indicate that each individual develops their personal choices based on their reasons or intentionalities, which are based on their experiences and are inscribed in the intersubjective relationships of the life world, being permeated by historical and cultural constructions, which situates each individual biographically.

It is understood, in the present study, that the woman is biographically situated and will permeate her choices in the childbirth process based on reasons for such actions, according to her experiences in the life world. Thus, the research question was: What are women's autonomous actions during childbirth and their reasons? 
It order to answer this question, Alfred Schütz's Social Phenomenology ${ }^{16}$ was chosen as the study's theoretical-methodological framework, which stands on the understanding that human actions in the life world are based on "reasons for" and "reasons why". The former refers to the intentionalities in which actions result from motivations, projects and expectations for the future or for the act performed (reasons for). The latter refers to reasons based on previous experiences during life and the present time (reasons why).

Therefore, it is considered that this woman's experiences are not restricted to an individual intentionality, but to the construction in the social sphere, constituting an intentionality that translates her experience in the context of social relations permeated by intersubjectivity. Thus, the objective of this study was to describe women's autonomous actions during childbirth and to understand their reasons.

\section{METHOD}

This is a qualitative research, designed according to Alfred Schütz's Social Phenomenology premises, which allows the understanding of the subjectivity of human actions in the context of intersubjective social relations in the life world. According to Alfred Schütz, action is a human conduct designed in a conscious and intentional way to meet the individual's expectations. Such expectations are determined by their biographical situation arising from their history based on previous experiences that make up their set of knowledge. These aspects are present in the intentionalities that can be guided by future projects and expectations (reasons for), and also reasons based on present and past experiences (reasons why). ${ }^{16}$

Thus, in order to understand motivations, some concepts are added, such as biographical situation, set of knowledge, reflective attitude, natural attitude, which allow to understand the social phenomenon. ${ }^{16}$ In social phenomenology, the determined biographical situation is the sedimentation of all experiences, ${ }^{16}$ which adds subsidies to understand the reasons for women's autonomous actions during labor and delivery, while allowing visibility to aspects that constitute it. The phenomenon of labor and delivery surrounds these women's life world in their social relations and in their experiences, through which the set of knowledge is constituted.

The study site was the rooming-in setting of a tertiary-level university hospital with a multidisciplinary team, a reference service in the care of high-risk pregnant women in the center of Rio Grande do Sul, Brazil. Fifteen postpartum women participated in the study, whose eligibility criteria was to have had labor and delivery assisted at the institution; and the exclusion criteria were indication for cesarean section prior to labor, severe maternal pathologies or fetal death. In order to check the eligibility criteria, the medical records of women hospitalized at the time of data collection at the obstetric hospitalization unit were accessed. Through them, a list of postpartum women with the potential to share information about the object of study was created.

The women were interviewed individually after the explanation and signature of the Informed Consent Form. The data generation stage started with the researcher approaching and adaptating to the setting in order to know the assistance routine in rooming-in and the organization of medical records, to elect a room for interviews that would guarantee privacy and anonymity and to approach the possible study participants.

The participants were approached through an informal conversation in which they were invited to participate in the study and, if they accepted, they were taken by the researcher to a reserved place. Regarding the newborn, it was discussed with the woman and her companion whether the infant would accompany her or not, and whether the interview room would be informed to her companion. Such strategy aimed to minimize the possibility of the woman feeling anxious and concerned about the infant, in order to allow a deeper phenomenological interview. 
The phenomenological interview was guided by a script with open questions based on the adopted theoretical framework and on the study's phenomenon. It should be noted that the questions were tested in the first interviews and only applied after adjustments. The leading questions were: "Tell me about your labor and delivery", "What did you do during this process?" and "Did you feel participative?". Then, the guiding phenomenological question emerged: "What did you have in mind when you performed such action?". When conducting the interview, in order to minimize assumptions, the researcher needed to focus on the research participants' understandings in a face-to-face relationship, in which she faced the participant without any object between them. This enabled each woman to freely express her motivations, which were recorded in a notebook in order not to interrupt the woman's speech. After the participant finished her explanations, the notes were reintroduced in order for her to deepen her reasons. ${ }^{17}$

The interviews were recorded in the field stage, which took place from September to December 2017 , and ended when the objective of the study had been answered. ${ }^{18}$ To this end, the analysis was carried out during the period of the interviews. As the interviews were conducted, the previous ones were transcribed, read and analyzed. Thus, the empirical material from the interviews was read and re-read in order to identify the women's actions and the motive (reasons why) for their actions. Then, a new reading was performed for the identification of similarities between the intentionalities. ${ }^{19}$ This enabled constructing concrete categories of what was experienced: due to fear of what they heard about labor and delivery; due to experiences of pain, complications and unwanted interventions; due to the bond with the companions and their experience with labor and delivery. During data analysis, the assumptions were minimized in order to enable the understanding of the phenomenon from the perspective of what was reported by the women.

The study was approved by the Research Ethics Committee and the participants signed the Informed Consent Form. The participants' anonymity was ensured by alphanumeric identification (P1, P2..., P15), in compliance with Resolution No. 466 of the Brazilian National Health Council (Conselho Nacional de Saúde) of December 2012.

\section{RESULTS}

The participants' ages ranged from 18 years to 36 years. Another aspect of the biographical situation is their profession, for example, those who worked in the health field tended to reflect on the situations they observed in the service, so they had already projected what they wanted for the childbirth. With regard to the person who accompanied them, their life partner represented $80 \%$. The women participating in this study were asked about which autonomous actions they took during the childbirth process, and the answers were important to contextualize the central question that would come later: to understand the reasons for women's autonomous actions during childbirth. In this study, the women's autonomous actions started in pregnancy and and were also present in childbirth. Such actions are described in Figure 1. 
Actions during pregnancy

- Performing exercises such as walking, pilates, squats;

- Seeking information about the childbirth process with people such as mother, sisters, health professional, friends;

- Choosing the type of delivery;

- Choosing a companion.
Actions during labor and delivery

- Looking for people nearby to seek information;

- Actions for pain relief (using the birthing stool, using the swiss ball, taking a hot shower);

- Squatting;

- Listening to music;

- Walking;

- Deciding when to seek the hospital;

- Choosing a companion.

Figure 1 - Actions taken by women in the exercise of their autonomy during labor and delivery - Santa Maria, RS, Brazil, 2017.

The women reported the actions that were developed during pregnancy as well as during labor. Such actions were signified (reasons for) by fear of what they had heard about labor and delivery, which influenced the choice for the type of delivery. The actions were also motivated by fear of cesarean section, pain, interventions and complications, which are shared by people close to the women. Such experiences in previous births motivate the search for autonomous or alternative actions so that they do not happen again.

The action of choosing companions was based on the affective relationship with these people, which was due to their participation during pregnancy, and also because they knew the woman's desires and could help to carry out what was planned. This reason explains the prevalent choice of their life partner as a companion. On the other hand, other women are chosen as companions because of their knowledge/experience about labor and delivery (Chart 1). 
Chart 1 - Central idea of the actions, illustrations and alphanumeric representation of other participants who presented thematic convergence in the reports - Santa Maria, RS, Brazil, 2017.

\begin{tabular}{|c|c|}
\hline \multicolumn{2}{|l|}{ Concrete Categories of What was Experienced: Reasons Why } \\
\hline \multicolumn{2}{|l|}{ Due to fear of what they had heard about labor and delivery } \\
\hline $\begin{array}{l}\text { I never wanted to have a cesarean section, I've always been very scared [...] because of } \\
\text { the recovery, the cut, the anesthesia. [...] I have already worked in a hospital, I've seen } \\
\text { a lot, and sometimes a cesarean section complicating (P3). I was afraid of a cesarean } \\
\text { section, [...] my sister underwent a cesarean section for her second child and she had a } \\
\text { cardiac arrest (P7). }\end{array}$ & $\begin{array}{c}\text { (P2) (P4) } \\
\text { (P6) (P8) } \\
\text { (P9) (P11) } \\
(\mathrm{P} 13)(\mathrm{P} 15)\end{array}$ \\
\hline \multicolumn{2}{|l|}{ Due to experiences of pain, complications and unwanted interventions } \\
\hline $\begin{array}{l}\text { Because in my previous births I felt pain only at the hospital [...] I didn't want to go } \\
\text { through the process of taking pills or saline solution [...] as in the other ones [...] so } \\
\text { I waited longer at home (P1). Because for the first child I didn't know [...] I wanted } \\
\text { everything to be very natural, I didn't want induced labor [...] because on the previous } \\
\text { time, it was induced and I found it much more difficult. [...] the only thing I chose was } \\
\text { that I didn't want the baby to be forced to come using saline solution, and I didn't want a } \\
\text { cesarean section [...] and as I already knew the pain of childbirth, I tried hard (P9). }\end{array}$ & $\begin{array}{c}\text { (P3) (P7) } \\
\text { (P8) (P13) } \\
\text { (P12) P15) }\end{array}$ \\
\hline \multicolumn{2}{|l|}{ Due to the bond with the companions and their experience with labor and delivery } \\
\hline $\begin{array}{l}\text { We've done everything together since the beginning of the pregnancy, from the time we } \\
\text { suspected, because we had already been trying to get pregnant for } 7 \text { months. Since } \\
\text { we learned about the suspected pregnancy, he's always participated a lot. So he had to } \\
\text { be there (P3). Since the beginning of the pregnancy I wanted him with me [husband]; } \\
\text { as he had already seen the other one, he also stayed with me this time [...] he's always } \\
\text { participated a lot in the pregnancy, from massaging the belly to applying cream, oil, he } \\
\text { always did it, he wanted to. He's very rational, strong, he doesn't get desperate, he's } \\
\text { very calm, he calms me down (P10). My mother, [...] at the time of the delivery it was } \\
\text { fine, my mother was with me. [...] Mothers will be mothers; for being a mother, only she } \\
\text { could know what I was going to go through (P5). I was with my sister, I preferred her, } \\
\text { because she is more relaxed, she already has children (P14). }\end{array}$ & $\begin{array}{l}\text { (P2) } \\
\text { (P4) } \\
\text { (P8) }\end{array}$ \\
\hline
\end{tabular}

\section{DISCUSSION}

The reasons for the actions of the women participating in this study are due to fear of what they have heard about the process of labor and delivery. From the perspective of social phenomenology, their reasons can be understood based on the social relations included in the life world. ${ }^{18}$ The life world in a historical-cultural process was pre-structured by the predecessors, and it is passed on through face-to-face relationships, which makes it possible to transmit cultural aspects, customs, social norms and typical ways of behaving in front of certain situations, and it will be different in each society. In such historical-cultural process, individuals have a natural attitude, which is based on their set of knowledge and places them biographically. ${ }^{16,20}$

The social relationships and aspects that surrounded the women during pregnancy influenced their action to choose a type of delivery, since the shared information caused fear of cesarean sections, of pain during labor and delivery, of interventions and complications. Therefore, women's ambitions and expectations during pregnancy reflect the context in which they are included, supporting their choices during labor and delivery. ${ }^{21}$ In social phenomenology, through the system of interest, individuals emphasize aspects present in their set of knowledge that support their actions. ${ }^{20}$ Thus, experiences of labor and delivery shared by relatives or friends stand out and promote the constitution of interconnected codes in a system of interest, supporting the women's opinions and choices about the childbirth process. 
Therefore, it is possible to conclude that choosing a type of delivery is a construction in which women use the experiences of their predecessors and contemporaries, and such experiences are still strongly permeated by conceptions of the interventionist obstetric model. Thus, for women to achieve their autonomy, they need to constantly reaffirm their conceptions and desires in a way that surpasses the natural attitude. ${ }^{22-23}$

One possibility for the fulfillment of their desires is the access and availability of information during pregnancy, which can occur during prenatal care and in the relationships with social actors, since, in addition to the information, choosing a type of delivery also involves family and cultural aspects. ${ }^{22}$ The preference for vaginal delivery or cesarean section, in addition to being an individual discourse, is inserted in the social space, conditioning the way these women conceive the experience of childbirth and directly influencing their choice. ${ }^{24}$

Other aspects evidenced in the reasons for the actions of the women in this study are the experiences of pain, complications and unwanted interventions, which are present in their set of knowledge and are accessed to support their autonomous social actions, so that such events do not happen again. These aspects are related to the suffering generated by the interventions. The experiences that caused suffering in previous deliveries lead women to search for alternatives in childbirth. ${ }^{25}$ Thus, supported by the desire to avoid the repetition of a bad previous childbirth experience, they seek subsidies to be able to control their deliveries so that interventions do not take place. ${ }^{21}$

This movement towards phenomenology represents the reflexive attitude, in which women stop acting in their natural attitude and intentionally seek the meaning of the phenomenon in order to understand the situation experienced. ${ }^{20}$ Such understanding makes it possible for them to change their actions. ${ }^{26}$ This allows women to create codes in their set of knowledge and to use them in their actions. ${ }^{16}$

In this reflexive attitude, the information from their set of knowledge and the search for information allow women to situate themselves in relation to their decisions regarding labor and delivery and strengthen their autonomy. ${ }^{21}$ The main knowledges are the recognition of the beginning of labor and knowing how to act to increase dilation and reduce pain. In possession of these codes, women have in the exercise of their autonomy actions motivated to not suffering during labor and, to this end, they use non-pharmacological methods of pain relief and activities for dilation, which they perform in their homes, thus using some of the practices also recommended by the $\mathrm{WHO}{ }^{9}$

This action promotes women's autonomy and favors the humanization process of childbirth care, as women seek to question certain procedures and defend their desire to give birth according to their lifestyles and beliefs. ${ }^{27}$ Information and knowledge about the process labor and delivery is a possibility for women to have their deliveries as they wish, without interventions and with autonomy. On the other hand, lack of information about this process can result in passive attitudes from women, reinforcing the idea that childbirth is better conducted by professionals and emphasizing the benefits of interventions. ${ }^{28}$

The third concrete category of what was experienced that evidenced the reasons for women's actions in this study was choosing companions due to bonds and because of the companion's experience with labor and delivery. Thus, it is possible to evidence the relationship established with these actors during pregnancy, which, in this study, were mainly partners/husbands.

When assessing the woman's satisfaction regarding the support and convenience of their partners as companions during the childbirth process, it appears that when they only participate in prenatal appointments, their support during childbirth is restricted to the moment of labor. However, such support is extended when the companion also engages in educational activities carried out during prenatal care, resulting in the women's satisfaction with the support during labor, delivery and immediate postpartum. ${ }^{29}$ Furthermore, the importance of the presence of that social actor is due to the consolidation of the parent-child bond, as the family intercommunication network starts to develop in this phase. ${ }^{30}$ 
Choosing a companion is associated with this actor's set of knowledge, as is the choice for other women (mother/sister). The choice for a companion is based on a bonding relationship that the woman establishes with that actor. The presence of other women reduces fear, as they are familiar with labor and delivery and can help to conduct this process based on their experiences.

In this study, most women chose their life partners, as they were present during pregnancy and knew the woman's desires. This choice allows the improvement of the bond as a partner and the paternal presence. Thus, the participation of family members or people chosen by the woman (re) connects conceptions about childbirth as a family and social event permeated by different cultures. In this context, it is important to emphasize that respecting, valuing and encouraging the choice of a companion by the mother is the component that contributed the most to a positive experience for all involved. ${ }^{30}$

This study presents as a limitation the possibility that the actions and reports of the research participants are influenced by the information and speeches of professionals from the obstetric sector.

\section{CONCLUSION}

From the perspective of Alfred Schütz's Social Phenomenology, we understand that the reasons for women's autonomous actions in childbirth are based on their biographical situation, set of knowledge and social relations. Despite the reasons for women's autonomous actions during childbirth, these reasons aim to meet the singular desires of each woman, even if such desire emanates from experiences in intersubjective social relationships related to the phenomenon of childbirth.

In conclusion, this study indicates that in order to guarantee the full right of female autonomy, social preparation since pregnancy is necessary, considering, in addition to the biological aspects of pregnancy and childbirth, the cultural and social aspects that place each woman biographically in the life world. Professionals must base their conduct for pregnancy and childbirth on good care practices and on the singularity of each woman during the assistance, and they must also involve the social actors who share such experiences with the women, so that good practices in childbirth care can be present in their conceptions.

\section{REFERENCES}

1. Dodou HD, Rodrigues DP, Oriá MOB. O cuidado à mulher no contexto da maternidade: caminhos e desafios para a humanização. Rev Pesqui Cuid Fundam [Internet]. 2017 [cited 2019 Apr 10];9(1):222-30. Available from: https://doi.org/10.9789/2175-5361.2017.v9i1.222-230

2. Sanfelice CFO, Shimo AKK. Boas práticas em partos domiciliares: perspectiva 101 de mulheres que tiveram experiência de parto em casa. Rev Eletr Enf [Internet]. 2016 [cited 2019 Apr 10];18:e1159. Available from: https://doi.org/10.5216/ree.v18.31494

3. Jardim DMB, Modena CM. Obstetric violence in the daily routine of care and its characteristics. Rev Latinoam Enferm [Internet]. 2018 [cited 2019 Apr 10];26:e3069. Available from: https://doi. org/10.1590/1518-8345.2450.3069

4. Sadler M, Santos MJDS, Ruiz-Berdún D, Rojas GL, Skoko E, Gillen P, Clausen JA. Moving beyond disrespect and abuse: addressing the structural dimensions of obstetric violence. J Reproductive Health Matters [Internet]. 2016 [cited 2019 Apr 10];24(47):47-55. Available from: https://doi.org/10.1016/j.rhm.2016.04.002

5. Miller S, Abalos E, Chamillard M, Ciapponi A, Colaci D, Comandé D, et al. Beyond too little, too late and too much, too soon: a pathway towards evidence-based, respectful maternity care worldwide. Lancet [Internet]. 2016 [cited 2019 Jul 10];388(10056):2176-92. Available from: https:// doi.org/10.1016/S0140-6736(16)31472-6 
6. Freedman LP, Kruk ME. Disrespect and abuse of women in childbirth: challenging the global quality and accountability agendas. Lancet [Internet]. 2014 [cited 2019 Jul 10];384(9948): e42-e44. Available from: https://doi.org/10.1016/S0140-6736(14)60859-X

7. Junges CF, Bruggemann OM, Knobel R, Costa R. Support actions undertaken for the woman by companions in public maternity hospitals. Rev Latinoam Enferm [Internet]. 2018 [cited 2019 Apr 10];26:e2994. Available from: https://doi.org/10.1590/1518-8345.2251.2994

8. Brasil. Ministério da Saúde. Secretaria de Ciência, Tecnologia e Insumos Estratégicos. Diretriz Nacional de Assistência ao Parto Normal: relatório de recomendação. Brasília, DF(BR): MS; 2016. Available from: http://conitec.gov.br/images/consultas/2016/relatorio_diretriz-partonormal_cp.pdf

9. WHO recommendations: intrapartum care for a positive childbirth experience. Geneva(CH): World Health Organization; 2018. Available from: https://www.who.int/reproductivehealth/publications/ intrapartum-care-guidelines/en/

10. Brasil. Ministério da Saúde. Portaria/GM n.569, de 1/6/2000. Institui o Programa de Humanização no Pré-natal e Nascimento. Brasília, DF(BR): MS; 2002. Available from: http://bvsms.saude.gov. $\mathrm{br} / \mathrm{bvs} /$ publicacoes/parto.pdf

11. Brasil. Ministério da Saúde. Assistência integral à saúde da mulher: bases da ação programática. Brasília, DF(BR): MS; 1984. Available from: http://bvsms.saude.gov.br/bvs/publicacoes/assistencia_ integral_saude_mulher.pdf

12. Brasil. Ministério da Saúde. Secretaria de Atenção à Saúde. Departamento de Ações Programáticas Estratégicas. Política Nacional de Atenção Integral à Saúde da Mulher: Princípios e Diretrizes. Brasília, DF(BR): MS; 2011. Available from: http://bvsms.saude.gov.br/bvs/publicacoes/politica_ nacional_mulher_principios_diretrizes.pdf

13. Brasil. Ministério da Saúde. Portaria GM n. 1.459, de 24 de junho de 2011. Institui, no âmbito do Sistema Único de Saúde - SUS - a Rede Cegonha. Brasília, DF(BR): MS; 2011. Available from: http://bvsms.saude.gov.br/bvs/saudelegis/gm/2011/prt1459_24_06_2011.htm

14. Pearson A, Jordan Z, Munn Z. Translational science and evidence-based healthcare: a clarification and reconceptualization of how knowledge is generated and used in healthcare. Nurs Res Pract [Internet]. 2012 [cited 2019 Mar 23];2012:CD792519. Available from: https:// doi.org/10.1155/2012/792519

15. Possati AB, Prates LA, Cremonese L, Scarton J, Alves CN, Ressel LB. Humanization of childbirth: meanings and perceptions of nurses Humanización del parto: significados y percepciones de enfermeras. Esc Anna Nery [Internet]. 2017 [cited 2019 Mar 23];21(4):e20160366. Available from: https://doi.org/10.1590/2177-9465-EAN-2016-0366

16. Schutz A. Sobre fenomenologia e relações sociais. Petrópolis, RJ(BR): Vozes; 2012.

17. Paula CC, Padoin SMM, Terra MG, Souza IEO, Cabral IE. Modos de condução da entrevista em pesquisa fenomenológica: relato de experiência. Rev Bras Enferm [Internet]. 2014 [cited 2019 Mar 23];67(3):468-72. Available from: https://doi.org/10.5935/0034-7167.20140063

18. Minayo MCS. Amostragem e saturação em pesquisa qualitativa: consensos e controvérsias. Revista Pesquisa Qualitativa [Internet]. 2017 [cited 2019 Mar 14];5(7):1-12. Available from: https://editora.sepq.org.br/index.php/rpq/article/view/82/59

19. Jesus MCP, Capalbo C, Merighi MAB, Oliveira DM, Tocantins FR, Rodrigues BMRD et al. The social phenomenology of Alfred Schütz and its contribution for the nursing. Rev Esc Enferm USP [Internet]. 2013 [cited 2019 Mar 23];47(3):736-41. Available from: https://doi.org/10.1590/ S0080-623420130000300030

20. Wagner HTR. Sobre fenomenologia e relações sociais: Alfred Schutz. Petrópolis, RJ(BR): Vozes; 2012. 
21. Sanders RA, Crozier K. How do informal information sources influence women's decision-making for birth? A meta-synthesis of qualitative studies. BMC Pregnancy and Childb [Internet]. 2018 [cited 2019 Mar 20];18:21. Available from: https://doi.org/10.1186/s12884-017-1648-2

22. Oliveira VJ, Penna CMM. Every birth is a story: process of choosing the route of delivery. Rev bras enferm [Internet]. 2018 [cited 2019 Mar 23];71(Supp 3):1304-12. Available from: https://doi. org/10.1590/0034-7167-2016-0497

23. Giaxa TEP, Ferreira MLSM. Miedo e inseguridad de la gestante durante el trabajo de parto como motivos para la demanda de internación precoz. Invest Educ Enferm [Internet]. 2011 [cited 2019 Mar 10];29(3):363-9. Available from: http://www.scielo.org.co/scielo.php?script=sci_ arttext\&pid=S0120-53072011000300004\&lng=en\&nrm=iso

24. Weidle WG, Medeiros CRG, Grave MTQ, Bosco SMD. Escolha da via de parto pela mulher: autonomia ou indução? Cad Saúde Coletiva [Internet]. 2014 [cited 2019 June 10];22(1):46-53. Available from: https://doi.org/10.1590/1414-462X201400010008

25. Nascimento RRP, Arantes SL, Souza EDC, Contrera L, Sales APA. Choice of type of delivery: factors reported by puerperal woman. Rev Gaúch Enferm [Internet]. 2015 [cited 2019 June 30]; (36):11926. Available from: https://doi.org/10.1590/1983-1447.2015.esp.56496

26. Schutz A, Luckmann T. Las estructuras del mundo de la vida. Buenos Aires(AR): Amorrortu; 2009.

27. Queiroz TC, Fófano GA, Andrade FM, Oliveira MACA, Fontes LBA, Costa JA. Violência obstétrica e suas perspectivas na relação de gênero. Rev Científica Fagoc Saúde [Internet]. 2017 [cited 2019 Apr 15];2:65-72. Available from: http://revista.fagoc.br/index.php/saude/article/view/194/252

28. Sodré TM, Merighi MAB, Bonadio IC. Escolha informada no parto: um pensar para o cuidado centrado nas necessidades da mulher. Cienc Cuid Saúde [Internet]. 2012 [cited 2019 Jul 23]; 11:115-20. Available from: https://doi.org/10.4025/cienccuidsaude.v11i5.17062

29. Holanda SM, Castro RCMB, Aquin PS, Pinheiro AKB, Lopes LG, Martins ES. Influence of the partner's participation in the prenatal care: satisfaction of primiparous women regarding the support in labor. Texto Contexto Enferm [Internet]. 2018 [cited 2019 Jul 23];27(2):e3800016. Available from: https://doi.org/10.1590/0104-070720180003800016

30. Santos ALS, Oliveira ARS, Amorim T, Silva UL. O acompanhante no trabalho de parto sob a perspectiva da puérpera. Rev Enferm UFSM [Internet]. 2015 [cited 2019 Jul 23];5(3):531-40. Available from: https://doi.org/10.5902/2179769217337 


\section{NOTES}

\section{ORIGIN OF THE ARTICLE}

Article extracted from the dissertation -Autonomia feminina no processo de parto e nascimento: estudo fenomenológico na perspectiva das mulheres, presented to the Graduate Program in Nursing at Universidade Federal de Santa Maria, in 2019.

\section{CONTRIBUTION OF AUTHORITY}

Study design: Honnef F, Padoin SMM.

Data collection: Honnef F.

Data analysis and interpretation: Honnef F, Padoin SMM, Paula CC.

Discussion of results: Honnef $F$.

Critical writing and/or content review: Honnef F, Padoin SMM, Paula CC.

Final revision and approval of the final version: Honnef F, Padoin SMM, Paula CC.

\section{FUNDING INFORMATION}

This work was executed with the support of the CAPES - Coordenação de Aperfeiçoamento de Pessoal de Nível Superior - Financing Code 001.

\section{APPROVAL OF ETHICS COMMITTEE IN RESEARCH}

Approved by the Ethics Committee in Research with Human Beings of the Universidade Federal de Santa Maria, under Opinion No.1,287,340 and CAAE (Certificado de Apresentação para Apreciação Ética - Certificate of Presentation for Ethical Consideration) 52157215.9.0000.5346.

\section{CONFLICT OF INTEREST}

There are no conflicts of interest.

\section{HISTORICAL}

Received: October 4, 2019.

Approved: Abril 1, 2020.

\section{CORRESPONDING AUTHOR}

Stela Maris de Mello Padoin

stela.padoin@ufsm.br 